\title{
The Travails of Women and Girls in Northern Nigeria: A Human Rights Issue
}

\author{
Adah Ogbe , Saint Mary’s University
}

\begin{abstract}
The vulnerability of women and girls in Northern Nigeria is likened to an 'endangered specie' that struggles daily to survive. That region of the country is notorious in negativities: poverty, illiteracy, unemployment, insecurity and now, blatant abuse of health and reproductive rights of women and girls. This article, hence, exposes the precarity that pervades the region and highlights the factors above and how women and girls have been made scapegoats by the socio-cultural, economic and religious establishment in Northern Nigeria. Using statistics and scholarly finding of researches and literature, the article articulates these factors, which include but not limited to, abuse of the health and reproductive right of women and girls, illiteracy and early marriage and insecurity. The article concludes by calling the government of Nigeria to treat the condition of women and girls in the Northeast as an emergency, by setting up structures headed by or headed by shared leadership roles of women, that will investigate their situations and proffer solutions. An Empowerment Education Fund should be created to provide accessibility for compulsory primary, secondary and even tertiary education to the girl child in Northern Nigeria.
\end{abstract}

Keywords: Women and girls, Health and reproductive rights, Literacy, Child marriage, Conflict

\section{Résumé}

La vulnérabilité des femmes et des filles du nord du Nigéria est associée à une "espèce menacée» qui lutte quotidiennement pour survivre. Cette région du pays est célèbre pour ses aspects négatifs : pauvreté, analphabétisme, chômage, insécurité et maintenant, abus flagrants des droits des femmes et des filles en matière de santé et de reproduction. Cet article expose donc la précarité qui règne dans la région et met en évidence les facteurs mentionnés ci-dessus ains que la façon dont les femmes et les filles ont été faites bouc émissaires par l'establishment socioculturel, économique et religieux du nord du Nigéria. En utilisant des statistiques et des résultats de recherches et la littérature, cet article articule ces facteurs, qui comprennent sans s'y limiter, l'abus des droits des femmes et des filles en matière de santé et de reproduction, l'analphabétisme, le mariage précoce et l'insécurité. L'article conclut en appelant le gouvernement du Nigéria à traiter la condition des femmes et des filles dans le Nord-Est en tant qu'urgence, en mettant en place des structures dirigées par ou partiellement par des femmes qui enquêteront sur leur situation et proposeront des solutions. Un Fonds d'éducation pour l'autonomisation devrait être créé pour permettre aux filles du nord du Nigéria d'accéder à l'éducation primaire obligatoire, secondaire et même à l'enseignement supérieur.

Mots-clés : Femmes et filles, Santé et droits reproductifs, Alphabétisation, Mariage d'enfants, Conflit

\footnotetext{
*Biography :

Adah Ogbe, M. is currently working with the Development and Peace- Caritas Canada, the international development organization of the Catholic church in Canada. He has a background in Philosophy and Theology and had worked with nonprofit/religious organizations in Nigeria. He recently graduated from Saint Mary University, Halifax, NS, with a Master's in International Development Studies, in addition to the master's in Development Communication he backed from Ahmadu Bello University, Zaria, Nigeria. His thesis focus was on "The Role of Pentecostal churches in Human Development in Nigeria". He was also the past project director of the CIHR-funded Project on violence against women migrants and refugees.

Biographie :

Adah Ogbe, M. travaille actuellement avec Développement et Paix - Caritas Canada, l'organisation de développement international de l'église catholique au Canada. II a une formation en philosophie et en théologie et a travaillé avec des organisations religieuses/à but non lucratif au Nigéria. II a récemment obtenu une maîtrise en études du développement international à l'Université Saint Mary's à Halifax en Nouvelle-Écosse, en plus d'une maîtrise en communication du développement de l'Université Ahmadu Bello à Zaria au Nigéria. Sa thèse portait sur le rôle des églises pentecôtistes dans le développement humain au Nigeria. II a également été directeur du projet financé par les IRSC sur les violences faites aux femmes migrantes et réfugiées.
} 


\section{Introduction}

Our society has grabbled with gender discrimination, injustices and sexual exploitation of women and girls. These injustices remain steep in various forms in our customs, culture and religious practices in many developing and, in subtle forms, in developed countries (Nmadu et al., 2016). Some scholars have held the view that this has been so from time immemorial (Marx, 1848; Fisho-Orideji, 2001; Woods, 2001; Igube, 2004, cited in Alabi et al., 2014). Consequently, this biased and prejudicial stance has manifested in various forms such as female feticide, female infanticide and sexual abuses. Women and girls have also experienced discrimination in nutrition, health care and education (Tiwari, 2013; ISGlobal, 2016). There are records of violent prejudices against women and girls in other aspects of life such as social, political, and economic spheres especially in African and Asian countries (Alabi et al., 2014).

There are many research articles on the state of the average woman and girlchild in Northern Nigeria (Action Aid, 2011; Maigari et al., 2012; Ibrahim, 2016; APHC, 2017). That region of Nigeria, predominantly Hausa-Fulani Muslims, is notorious for its poverty levels. There are millions of out of school children, and children on the streets begging (called Almajiris). The practice of prebendal system, conspicuous hegemony and patriarchy are found there, as the elites perpetually dominate the masses. Although these studies expose the conditions of these women and girls, sadly, most researches do not make a categorical case for the ruptured human rights of these women and girls that are often violated bodily and psychologically (Ezeanochie, et al., 2010; Maigari et al., 2012; Alabi et al., 2014; Ibrahim, 2016; Nmadu et al., 2016; APHC, 2017). This results in untold adverse effects on their health and reproductive health rights, and a lukewarm attitude by government agencies and those saddled with such responsibilities.

This paper stands by Article 25 of the Universal Declaration on Human Rights (UDHR) that articulates the right to adequate health, thus: "Everyone has the right to a standard of living adequate for the health and well-being of him (her) self and of his (her) family, including food, clothing, housing and medical care...". The paper, therefore, concludes amidst all that women and girls are confronting, they remain an "endangered species" in Northern Nigeria. The defunct Millennium Development Goals (MDGs) No. 5 which many countries pursued vigorously stated as its target; to improve the ratio of maternal health by three quarters between 1990 and 2015, and target 5(b) aimed at achieving by 2015, a universal access to reproductive health. However, this remains an ambitious goal many years after the program ended. This goal was further taken over into the Sustainable Development Goals (SDGs) No. 3 whose target is 'By 2030, reduce the global maternal mortality ratio to less than 70 per 100,000 live births'. Nevertheless, the quality of life of women and girls in Northern Nigeria faces an existential threat.

This article posits that women and girls in Northern Nigeria fall within the lower rungs of maternal health development globally and face horrendous situations that rob them of their reproductive and health rights as human beings, simply because they are women and girls. The tide seems to work against them in all fronts putting the achievement of these SDGs in jeopardy. To put it in context, Fisho-Orideji, (2001) argues that traditional society viewed the birthing of a girl child as a curse (cited in Alabi et al., 2014). The paper further advances that the situation is an emergency that needs the attention of all stakeholders, out of respect for the fundamental rights of all persons, to embark on collective action, to build free health facilities, schools, ensure peace and basic needs to women and girls in Northern Nigeria. It further makes a strong case for this state of emergency position by exposing and explicating some of the current realities that endanger the reproductive and health rights of women and girls in Northern Nigeria.

\section{Health and Reproductive Rights of Women and Girls}

The health and reproductive rights of women and girls is understood to mean that women and girls have access to reproductive health care services and can make decisions regarding their sexuality and reproduction (Amroussia et al., 2016). Although, these rights remain controversial in some quarters because of the antithetical stance of the religious-cultural beliefs of people in Northern Nigeria, they are not new. They are embedded in the fundamental human rights of each individual 
enshrined in the United Nations Declaration on Human Rights (1949) which are universal and inalienable, and were further reaffirmed by both the International Conference for Population Development (ICPD) in 1994 and the Fourth World Conference on Women in 1995 in Beijing (Austin et al., 2008; Amroussia et al., 2016). As pointed out by Amroussis et al. (2016), the rights of women is interwoven with gender dynamics of a given context. Gender discrimination is partly to be blamed for the precarious situation of women and girls in Northern Nigeria. Many of them have resigned to their fate by accepting gender-based violence, gender discrimination and other forms of abuse as their lot (Amroussis et al., 2016). Until they are truly emancipated and empowered politically and economically to make free decisions relating to reproduction and reproductive health, women and girls cannot be said to fully enjoy their fundamental rights (Nmadu, 2010; Nwogwugwu, 2020).

As of 2017, it was a dangerous thing for a woman to be pregnant in Northern Nigeria (APHRC, 2017) and the situation has not changed much. However, statistics on maternal mortality globally have showed a steady decrease (Ogu et al., 2016). The number of maternal deaths fell from 546,000 in 1990 to 358,000 in 2008 per year, that is, a 34\% decrease. At the regional level, maternal deaths dropped within the same period in all regions except sub-Saharan Africa and Oceania. On the contrary, maternal mortality increased slightly in sub-Saharan Africa (from 199,000 to 204,000) (Zureick-Brown et al., 2013). Nigeria has the second largest record of maternal death after India (Yaya et al., 2018). Every 13 minutes, a woman dies because of pregnancy related issues in Nigeria. Hemorrhage and unsafe abortions are the principal causes of these deaths (APHRC, 2017). The United Nations and The World Bank statistics rate Nigeria as one of the worst countries for women to deliver babies in the world, with an estimated 144 women dying each day from pregnancy related complications (APHRC, 2017). Nigeria has an annual maternal death of 40,000 women and girls that is, $14 \%$ of the global total (Yaya et al., 2018). Out of the recorded 9.2 million women pregnant in 2017, 1 in 13 would have experienced maternal death compared to the 1 in 31 in sub-Saharan Africa. Findings indicate that 1 in 4 of these 9.2 million pregnancies is unintended; hence, abortion becomes the most sought option. And most of the time, unskilled health practitioners perform such abortions in an environment lacking minimum standards. The rate of abortion is 31 per 1,000 (APHRC, 2017).

Within the country, there is disparity in rates of maternal mortality between the North and the South. Maternal mortality is higher in the North with a staggering figure of 2,420 per 100,000 births while the South has a rate between 454 and 772 per 100,000 births (Ezeanochie et al., 2010; Yaya, et al., 2018). Worthy of note, the Northeast is notorious in maternal death. There are 1,549 maternal deaths per 100,000 in the Northeast (Federal Ministry of Health, 2011, 2015) and rural women face the highest risks compared to the urban women. One reason among many others, is that rural women tend to give birth at home or visit unskilled birth attendants. The statistics show less than $50 \%$ of pregnant women receive antenatal care, $41 \%$ and $49 \%$ in the Northwest and Northeast respectively compared to $90 \%$ and $91 \%$ in the Southwest and Southeast (Nigerian Health Review (NHR), 2006). Furthermore, only a third of women seek the recommended postnatal care, and barriers to this lack of postnatal care includes cost of services, distance to health facilities and long waiting time for those visiting the public health facilities (APHRC, 2017, p.3). Other reasons scholars identified include sociocultural and economic conditions, weak policy implementations, education, gender, geography, race and religion (Maigari et al., 2012; Ogu et al., 2016). Let it be emphasized here, religion has a strong influence in shaping the lives of individuals regarding reproduction and sexuality especially in Northern Nigeria (Ogu et al., 2016; Dalton, 2013).

The Nigerian government has not been fully committed to remedying the situation, a situation Tania Li calls the case of 'let die,' i.e. when a government chooses not to pursue policies that will improve the health and welfare of its people (Li, 2009). Within the period of 1999 to 2014, Nigeria's national budget on health was between $2.70 \%$ and $7.00 \%$ of total yearly budget (Budget Office of the Federation, 2015). In 2000 and 2001, Nigeria invested $0.2 \%$ of its GDP in the health sector. With corruption and poor infrastructure in the country, the health sector has continued to drop in quality and service delivery (Omotola, 2008). This low investment in health informed the government's commitment of $6 \%$ of its budget from the year 2012 to 2015 to the health sector. Despite the pledge to commit $15 \%$ during the Abuja Declaration in 2001, the government has not held its commitment, rather the percentage dropped to 4.64\% in 2016 (APHRC, 2017). A survey carried out by the World 
Health Organization ranks Nigeria as number 189 among the 201 countries in 2015 in terms of the health system in the country (WHO, 2015). This invariably affects the human capital development of the country, the economic productivity of the people and in extension, the economy of the nation (Ibrahim, 2016). A study published in the African Regional Health Report (2014), shows that the productive labour of healthy population contributes to the economic growth of a country: "for every $10 \%$ increase in life expectancy at birth there is a corresponding rise in economic growth of $0.4 \%$ per year" (African Regional Health Report, 2014, p.6). Therefore, for Nigeria to lose such a huge number of women and girls to death every year due to reproductive health complications is worrisome and detrimental to the economy and something ought to be done urgently.

\section{Literacy and Early Marriage}

Some scholars hold the view that education is a requirement for human capital development, which is the bedrock of any sustainable economic development (Nmadu et al., 2010; Chinwudu et al., 2016). No country's development is sustained when women are excluded from access to education. The World Bank stated it better; that educating the girl-child is a prerequisite investment in building the economy (Nmadu et al., 2010; Alabi and Alabi, 2013). Hence, this prevalent belief has spurred governments across the world to invest massively in education with the end goal, to engender development. For example, Osaru and Umaru (2017) observed the incredible human capital development in Japan and Germany between 1948 and 1972, and the reason was attributed to the massive investment in education via technology where the general productivity of an individual rose by $8.2 \%$ in Japan and $5.7 \%$ in Germany in one year.

The adult literacy rate in Nigeria, according to the National Bureau of Statistics after a National Literary Survey in 2010, is estimated as $56.9 \%$, with variations between states (Lagos $92.0 \%$ and Borno $14.5 \%$ ), and sex (male $65.1 \%$ and female $48.6 \%$ ). Borno state is in the Northeast of Nigeria while Lagos is in the South. Nigeria has an estimated $20 \%$ of the total number of out-of-school children globally (Global Partnership for Education, 2019). An earlier report estimated a rise in the number of out of school children from 10.5 to 13.2 million between 2010 and 2015, with $60 \%$ of those children from the North (UNICEF, 2013; Development Cable, 2018). Moreover, the situation is turned for the worse in Northern Nigeria where almost two-thirds of students cannot read and write in English (Global Partnership for Education, 2019). 70\% of young women (age 15-24) in the Northwest Nigeria have not completed primary school (UNESCO, 2014; GEN Report, 2014).

According to UNICEF report, only $20 \%$ of women in the Northwest and Northeast of the country can read and write while the Northcentral and Northwest remains worse (Alabi and Alabi, 2013). Studies show that lack of accessibility to schools is a huge setback to girls' enrolment and retention in school. This is despite the policy on universal basic education for every child. The United Nations General Assembly (UNGA) states that education is the fundamental right of every child (1989). This policy has been ratified by the 196 member-nations of the UN and requires every member-state "to provide every child an equal opportunity to receive compulsory and free primary education and to have access to secondary schools or vocational training" (UNGA, 1989; UNICEF, 2015; Roby et al., 2016). The 1985 Nairobi Declaration and the 1990 World Declaration on Education for all, further reaffirmed the necessity of education and Nigeria has gone ahead to deploy various strategies, policies and programs to improve levels of female education by successive governments. Hence, any country that does not provide basic education to its citizen is infringing on the fundamental rights of its people. Nigeria, on this case, has domesticated this instrument as a local policy. According to the National Policy on Education (2004),

basic education covers nine years of formal (compulsory) schooling consisting of six years of primary and three years of junior secondary. Just one-third of children who begin basic education currently proceed to senior secondary school (NBS, 2016, p.112).

However, the situation has not changed for the better and neither is it more palatable in the countryside. In many rural areas in the northern region; children walk many kilometers to reach the nearest school to their community. For example, research found that $14 \%$ of girls surveyed walked 
over six kilometres to school every day. Many girls (61\%) walked between 1 to 3 kilometres. In an earlier survey conducted in 2008 in the Northern states of Nigeria, $21 \%$ of girls viewed distance to school as a major obstacle to girl-child education (GEN Report, 2014). This is because, unlike their boy counterparts, they also engage in more house chores. Some of them come to school already exhausted as a result of distance and hunger and, are likely to sleep while classes are going on. Another reason parents pull the girl-children out of school into various forms of work, such as hawking, nannies, domestic helps etc., is to make money for the family. UNICEF (2003) estimates that 15 million children work full time in Nigeria, the majority of whom are girls dropped out of school in the Northern states. This is a clear abuse of the fundamental human rights of women and girls.

Sadly, Nigeria's poor funding of education persistently hinders access to education. In recent years, the figure has not only been on the decline but is far below the recommended benchmark of $26 \%$ of a country's budget set by UNESCO (UNDP, 2015; Chinwudu et al., 2016). According to the Budget office of the Federation (2015), between 2005 and 2014, the annual budget on education was $6.86 \%$ (Ibrahim, 2016). With poor funding of education comes massive illiteracy among the populace. The finding of a survey by the Federal Commission for Mass Literacy, Adult and Non-Formal Education, show more than $47.5 \%$ or 60 million Nigerians are still illiterate in the new millennium (FCMLANE, 2010). As a result, the United Nations Development Program places Nigeria's educational system at the 90th position in the world in 2015 (UNDP, 2015).

The 'son-preference' syndrome is a common phenomenon of the patriarchal system in Northern Nigeria which has caused collateral damage to the girl-child education as parents see boys as those to continue the family lineage while the girls would be married out to bear someone's name (Alabi et al., 2014). Since girls are to be married out, there was no need to invest in educating the girlchild as it benefits the family she is married into, so thought some parents (Alabi and Alabi, 2013). Others express hostility towards girls' schooling giving reasons of westernisation and loosening of morals. In other words, educating the girl-child is perceived as losing of traditional values encouraging premarital sex and unwanted pregnancy, and to avoid that, girls are kept out of school and married out early (GEN Report, 2014; Alabi et al., 2014). Such cultural norms are common practice in Northern Nigeria and infringes on the rights of the girl child. Community and religious leaders are crucial stakeholders in sensitizing the communities/families on the significance and the gains of educating the girl child in the community.

Early and forced marriage has been the cultural norm and indeed religious, in Northern Nigeria because parents fear pregnancy outside of marriage. The girl children in their early years, about 12 or even less, are given out in marriage to friends, benefactors, strangers, visitors, elders, cleric etc. At times, even against the wishes of these girls, they are married out to men old enough to be their grandfathers (Alabi et al., 2014). Indeed, parents make a fortune through bride payments on their daughters. Even though the federal Child Rights Act (2003) prohibits under-18 years old marriage in Nigeria, not all states in the North have domesticated the Act and many girls under 18 in the North are married out with or without their consent. In 2008, $28 \%$ of young women aged 15-19 years surveyed were already married, compared to $1 \%$ of young men. Among these young women, $12 \%$ were married by 15 years of age and $26 \%$ were already in a polygamous union with one or more cowives (NPC, 2009). This is the reality of girl children in Northern Nigeria and unfortunately religiouscultural practices enhance this flagrant abuse of the rights of women and girls. This should collectively be condemned as unacceptable.

Early marriage, then, poses an obstacle and remains a threat to continuing girlchildren education in Northern Nigeria as it accounts for lack of school retention. "Among girls surveyed in six Northern States in $2008,43 \%$ cited early marriage as a major obstacle that would prevent them from continuing their schooling and 32\% cited pregnancy" (British Council Report, 2014, p.26). The research findings conducted by Nmadu et al. (2010) in Zaria, Northwest of Nigeria, showed that there was higher drop-out from primary school by girls in their fifth and sixth year, $14 \%$ and $10 \%$ respectively, compared to their male counterparts in their fifth (5\%) and sixth $(6 \%)$ years. The most probable reason is that parents removed their girl-children out of school in order to get them married at their puberty stage. Furthermore, parents see early marriages as a religious obligation leading to 
$60 \%$ withdrawal of girls from primary schools in Gombe and Adamawa States in Northeast Nigeria (NBS, 2010). The impact of the low literacy and early marriage leave grave consequences on women and girls in Northern Nigeria.

Some scholars made a nexus between education, maternal mortality and population, stating that educated women and girls are more likely to delay marriage and childbearing, and have healthier babies, access to prenatal and postnatal care than women with no formal education. Educating the girl child means she is empowered to make certain decisions that protect them from sexual exploitation, sexual diseases and gender malaise that confront them daily in different forms (Nmadu et al., 2010; Alabi et al., 2014). These scholars state:

Women with a secondary school education tend to have better knowledge about health care practices, are less likely to become pregnant at a very young age, tend to have fewer, better-spaced pregnancies, and are more likely to seek antenatal care, postnatal care, and skilled attendance at delivery. The effect is profound: for each additional year of schooling provided to young women, fertility declines by $10 \%$. In fact, it has been estimated that one additional year of school for 1,000 women would avert two maternal deaths. (Nmadu et al., 2010, p.108).

\section{Conflict in the Northeast}

Conflicts have a unique multitude of impacts on the health and rights of women and girls. In situation of conflicts, infrastructure such as health facilities, markets, water supply, sewage systems, and roads may be damaged or otherwise inaccessible (Dunn, 2018). According to the World Bank (2003), many African countries remain among the poorest in the world for myriad reasons among which are tribal wars and conflicts, thereby creating a human rights catastrophe. The person worst affected in these devastating situations is the girl-child. Many are taken as child soldiers or child brides and forcefully married out among members, or as trafficked and kidnapped victims, or sold as sex slaves, raped and even used as weapons of war. This touches on the core of their fundamental human rights as individuals as guaranteed by the United Nations Declaration on Human Rights.

The rise of the Islamist group, Boko Haram, in the Northeast, has tremendous negative impact on health indices in Northern Nigeria. Boko Haram, meaning 'Western education is forbidden', was founded around 2002 in Maiduguri, the capital of Borno state and the largest city in Northeast Nigeria (Dunn, 2018). The killing of its founder, Mohammed Yusuf, by the police triggered the armed confrontation with the government that degenerated into broad terrorist activities by the group. Part of its strategy is to launch attacks on civilian populations (soft targets) and abduct women, girls and children (UNDP, 2017, p.7). We have seen the abduction of Chibok and Dapchi schoolgirls numbering close to 400. Although some have been released through the government's negotiation with the group, many of them have yet to regain their freedom. Additionally, the insurgents have used the girlchildren forcefully kidnapped from their families as instruments of weapon when they were in captivity. It is on record that between January and July 2017, Boko Haram used 145 girls for suicide attacks across the Northeast (Okegbujo, 2018). This is a deliberate attack on the rights to life of women and girls. Indeed, this conflict, that of herders and farmers, armed kidnapping and banditry etc. have affected the entire Northern region thereby increasing the instability, economical retrogression and poverty in the North.

Studies show that in the worst affected Northeastern states (Borno, Adamawa, and Yobe), the conflict has rendered 5.1 million people in dire situation in need of special diets against famine. In addition, 1.2 million children under the age of 5, and pregnant and lactating women are malnourished (UNDP, 2017, p.7). The recent 2019 report by the International Organization on Migration (IOM) states that there are 4.2 million displaced individuals in Nigeria, Chad and Cameroon, neighbouring countries with Nigeria's Northeastern states. Hence, the conflicts have disrupted provisions of essential social services such as education, health, and water and sanitation as the militant group deliberately targets and destroys infrastructure, facilities and equipment. "In the health sector, 45 percent of all health facilities (including 21 hospitals) have been destroyed..." as insurgents target such public facilities in 
the Northeast (UNDP, 2017, p.8). Unfortunately, women, children and girls are worst affected in the on-going conflicts.

Another dimension to this conflict is the health rights concerns it poses. There has been a spate of rapes and sexual exploitations of women and girls facilitated by the conflicts. The insurgents' abuses on women and girls are numerous, namely: abduction, forced religious conversion, physical and psychological abuse, forced labour, forced suicide missions and forced marriage, rape, and other sexual abuses which have threatened women and girls in Northeast Nigeria (Read, 2017). Consequently, in January 2016, three UN Special Rapporteurs visited Maiduguri in Borno State and reported evidences of widespread sexual abuses within the internally displaced women's and girls' camps (Read, 2017). Furthermore, the prevalence of sexual abuses and exploitations of women and girls by civilian militias who are supposed to defend the victims is scandalous. Military personnel and the National and State governments' emergency management workers have equally been indicted in the sexual exploitation of women and girls by the report of the UN Special Rapporteur for Human Rights (Read, 2017).

In October 2016, a committee investigating allegations of trafficking and sexual abuses in Internally Displaced Persons (IDPs) camps found that the inability of women to provide food for their families makes them increasingly vulnerable to sexual exploitation in exchange for food or other assistance. By December 2016, officials at Bakassi IDP camp in Maiduguri, Northeast Borno State disclosed that between June and December, some 3,213 pregnancies had been recorded resulting from sexual abuses. Even the military camps carved out for IDPs is not immune as it has witnessed a preponderance of such sexual exploitations and abuses of women and girls. Women and girls in situations of conflict, such as the Northeast remain vulnerable and lack the capacity to provide basic needs of shelter, water and food for their family, hence, are susceptible to sexual exploitation (Read, 2017). Ultimately, some have embarked on forced internal and international migration. This vulnerability of women and girls exposes them to "predators" who abuse their rights indiscriminately as they remain unprotected even from those who are meant to protect them.

\section{Conclusion and Recommendation}

This paper is an expose of the conditions of women and girls in Northern Nigeria that put them in a precarious situation thereby depleting their rights to health, education and sometimes life itself. Hence, they live like endangered species that daily strive for survival in such a brutal manner. Being a girl or woman in present Northern Nigeria puts one into a position where everything seems to be working against you, to truncate achieving your full capabilities and fulness of life. If the insurgents are not on the trail to abduct, sexually molest, or sell women and girls as sex slaves; it is the security forces who are meant to protect them that would take advantage of them sexually, or it is the health risks involved in getting pregnant, or the lack of education which further demean the dignity and human rights of the girl children as many end up in early or forced marriages, or even succumb to patriarchal practices that denigrate womanhood in general. To add, the government, the culture, the religion and family values, does compound this precarity of women and girls in Northern Nigeria.

Government must be seen not to sit on the fence on the plight of women and girls, but rather, needs to roll out a comprehensive human rights-based response team that will address root causes of issues (patriarchy, customs, cultures, religious etc.) and respond immediately to complains of sexual exploitations to protect the civil, political, social, economic, and cultural rights of women and girls in Northern Nigeria. The authorities should activate referral mechanisms for women and girls in IDP camps putting women as leaders or part of the decision-making body. More so, it is important that culprits are made to face the full wrath of the law to serve as deterrents to others to forestall sexual abuse against women and girls especially in the IDP camps.

There have been various poverty alleviation programs in the past that failed. Efforts must continue, using women at the top echelon to supervise and coordinate policies of government to reduce poverty among women in the Northern states. Equally, a deliberate effort by the government in improving the health of women especially in Northern Nigeria by providing free health and medical services is imperative, especially reproductive health services. In addition, an Empowerment 
Education Fund for the girl-child is urgently needed so that the poor can have access to these funds to go to school.

\section{References}

African Population and Health Research Centre (2017). Maternal Health in Nigeria: Facts and Figures http://aphrc.org/wp-content/uploads/2017/06/APHRC-Maternal-Health-in-Nigeria--Facts-and-Figures.pdf Retrieved on 30-11-2018

African Regional Health Report (2014). The Health off the People that Works. Published by World Health Organization https://www.afro.who.int/sites/default/files/2018$03 / 9789290232612 \quad 0 \quad 0 . p d f$

ActionAid Annual Report (2011). http://www.actionaid.org/publications/actionaidinternational\%E2\%80\%99s-secretariat-plan-2011

Adepoju, A. (2006). Feminisation of Poverty in Nigerian Cities: Insights from Focus Group Discussions and Participatory Poverty Assessment

African Population Studies Supplement A vol 19/Etude de la population africaine Supplément A du vol. $19 \mathrm{http}: / / \mathrm{www}$.bioline.org.br/pdf?ep04024

Akegbejo, T. (2018). The Impact of Boko Haram's Insurgency On Girls' Education in Northeast Nigeria https://politicalinsights.org/2018/06/06/the-impact-of-boko-harams-insurgency-ongirls-education-in-northeast-nigeria/

Alabi, T. and Alabi O.S. (2014). Female education: A sociological analysis of girl-child Education in Nigeria. International Journal of Educational Policy Research and Review Vol.1 (1), pp. 006013, http://www.journalissues.org/journals/ijeprr/

Alabi T., Bahah M., and Alabi S.O. (2014). The Girl-Child: A Sociological view on the Problems of Girl-Child Education in Nigeria. European Scientific, vol.10, No.2

Amroussia N., Goicolea I., and Hernandez A. (2016). Reproductive Health Policy in Tunisia: Women's Right to Reproductive Health and Gender Empowerment, Health and Human Rights Vol. 18, No. 2, Special Section: Universal Health Coverage and Human Rights, pp. 183-194

Anyanwu, J. C. (2010). Poverty in Nigeria: A Gendered Analysis The African Statistical Journal, Volume, November 2010 https://www.afdb.org/fileadmin/uploads/afdb/Documents/Publications/Poverty\%20in\%20Nige ria\%20A\%20Gendered\%20Analysis.pdf retrieved 1-10-2018

Austin J., Guy S., Lee-Jones L., McGinn T., and Schlecht J. (2008). Reproductive Health: A Right for Refugees and Internally Displaced Persons, Reproductive Health Matters, Vol. 16, No. 31, Conflict and Crisis Settings: Promoting Sexual and Reproductive Rights, pp. 10-21

Bastos, A., Casaca, S. F., Nunes F., and Pereirinha, J. (2009). Women and Poverty: A GenderSensitive Approach. Journal of Socio-Economics, Vol. 38, No. 5 (October), pp. 764-78

British Council (2014). Girls Education in Nigeria Report 2014: Issues, Influencers, and Actions https://www.britishcouncil.org/sites/default/files/british-council-girls-education-nigeriareport.pdf pp 20-25 Retrieved on 7-12-2018

Brunelli, B. (2007). Structural Adjustment Programs and the Delivery of Health Care in the Third World. Pell Scholars and Senior Theses. Paper 16.http://digitalcommons.salve.edu/pell_theses/16

Chinwudu, C. F., and Nwaiwu, B. N., and Chikwe, G. C. (2016). The Contributions of Government Capital Expenditure on Education Towards Human Development In Nigeria (1980-2012) International Journal of Information, Business and Management, Vol. 8, No.3.

Dalton A-M, (2013). Beyond functionality: religion and international development, Canadian Journal of Development Studies / Revue canadienne d'études du développement, 34:2, 158-174, DOI: 10.1080/02255189.2013.782270

Dunn, G. (2018). The impact of the Boko Haram insurgency in Northeast Nigeria on childhood wasting: a double-difference study Conflict and Health https://doi.org/10.1186/s13031-0180136-2 retrieved 30th November, 2018.

Ezeanochie, M.C; Olagbuji, B.N; Agholor, K.N; Okonofua, F.E. (2010). Attaining MDGs in Northern 
Nigeria: Need to focus on skilled birth attendants African Journal of Reproductive Health Vol., No. 2pp. 9-15 https://about.jstor.org/terms Retrieved 3-01-2019

Federal Ministry of Health Report, $(2011,2015)$. Abujahttps://www.britishcouncil.org/sites/default/files/british-council-girls-education-nigeriareport.pdf retrieved 30th November, 2018

Human Development Report. (2015). Work for Human Development http://hdr.undp.org/sites/default/files/2015 human development report.pdf

Ibrahim, T. (2016). Human Capital-Growth nexus: the role of Government Spending on Education and Health in Nigeria. Munich Personal RePEc Archive (MPRA). Ahmadu Bello university Zaria, Kaduna State, Nigeria. https://mpra.ub.unimuenchen.de/73712/1/MPRA paper 73712.pdf

International Organization on Migration Report (2019). New Report Outlines Displacement, Human Mobility Figures in Lake Chad Basin https://www.iom.int/news/new-report-outlinesdisplacement-human-mobility-figures-lake-chad-basin

Institute for Global Health (2016). Inequalities in women's and girls' health opportunities and outcomes: A report from sub-Saharan Africa. Barcelona Institute for Global Health.https://www.isglobal.org/documents/10179/5808952/Report+Africa.pdf/a978fe4ad076-468b-805e-2f05861822d7

Kasomo, D. (2009). The factors militating against the education of girls: A case study in Kenya. International Journal of Sociology and Anthropology Vol. 1(7) 116-123, Available online http://www.academicjournals.org/ijsa

Li, T.M. (2009). To make live or let die? Rural Dispossession and the Protection of Surplus Populations Antipode Vol. 41 No. SI ISSN 0066-4812, pp 66-93 doi: 10.1111/j.14678330.2009.00717.x

Maigari. G.A., Geidam, A.D., Bako, B., and Ibrahim, A. (2012). Nigerian Lawyers and Reproductive Health Rights: A Survey of Knowledge Practice an Opinion on law Reforms among the BAR AND Bench in North Eastern Nigeria African Journal of Reproductive Health 16(1):69-74 https://about.jstor.org/terms retrieved 3-01-2019

Marx, K., and Engels. F. (1848). Manifesto of the Communist Party https://www.marxists.org/archive/marx/works/download/pdf/Manifesto.pdf

National Population Commission (2009). National Population Commission, Federal Republic of Nigeria, Abuja, Nigeria http://www.sciepub.com/reference/162179

National Bureau of Statistics (2010). Nigerian Poverty Profile Report 2010 https://www.proshareng.com/news/Nigeria\%20Economy/Nigerian-Poverty-Profile-Report2010---NBS/16302

National Bureau of Statistics. (2016). Annual Abstract Statistics 2016 https://www.proshareng.com/news/General/NBS-Annual-Abstract-of-Statistics-2016-/35588

Nigerian Health Review (2006). Publication of Health Reform Foundation of Nigeria (HERFON) https://www.herfon.org.ng/

Nmadu G., Avidime S., Oguntunde O., Dashe V., Abdulkarim B., and Mandara M. (2010). Girl Child Education: Rising to the Challenge. African Journal of Reproductive Health (Special Issue); 14(3): 107

Nwogwugwu, N. (2020) Women's Empowerment and Women's Health in Africa. In: Yacob-Haliso O., Falola T. (eds) The Palgrave Handbook of African Women's Studies. Palgrave Macmillan, Cham

Ogu, N.R., Agholor, N.K., and Okonofua, F.E. (2016). Engendering the Attainment of the SDGs-3 in Africa: Overcoming the socio-cultural factors contributing to maternal mortality African Journal of Reproductive Health, Vol., 20. No.3 Special Edition on SDGs, pp.62-74 https://about.jstor.org/terms Retrieved 3-01-2019

Omotola, J.S. (2008) Combating Poverty for Sustainable Human Development in Nigeria: The Continuing Struggle, Journal of Poverty, 12:4, 496-517, DOI: 10.1080/10875540802352621

Osaru, O.F., and Umoru, D. (2017). Economic Transformation and Human Development Index in Nigeria: An Econometric Evaluation of the Endogenous Growth Model. International Journal of Social Sciences \& Educational Studies ISSN 2520-0968 (Online), Vol.4, No.1, Doi: $10.23918 / i j s s e s . v 4 i 1 p 72$ 
Read, J. (2017). Sexual violence and the Boko Haram crisis in north-east Nigeria. Humanitarian Practice Network, October 2017 https://odihpn.org/magazine/sexual-violence-and-the-bokoharam-crisis-in-north-east-nigeria/

Roby, J.L., Erickson, L., and Nagaish, C. (2016). Education for children in sub-Saharan Africa: Predictors impacting school attendance. Children and Youth Services Review 64 (2016) 110-116 https://doi.org/10.1016/j.childyouth.2016.03.002

Tiwari, A. (2013). Gender Inequality in Terms of Health and Nutrition: Evidence from National Family Health Survey-3. Pacific Business Review International, Volume 5 Issue 12 https://www.researchgate.net/publication/268457918 Gender Inequality in Terms of Healt $\underline{\mathrm{h}}$ and Nutrition Evidence from National Family Health Survey-3

The United Nations Children's Fund (UNICEF). (2003). The State of The World's Children 2004 https://www.unicef.org/sowc04/files/SOWC O4 eng.pdf

The United Nations (2015).Transforming our World: The 2030 Agenda for Su stainable Development https://sustainabledevelopment.un.org/content/documents/21252030\%20Agenda $\% 20$ for $\% 20$ Sustainable\%20Development\%20web.pdf

Usman U. S. (2015). Women and Poverty in Nigeria: Agenda for Poverty Eradication Developing Country Studies www.iiste.org Vol.5, No.3, 2015 retrieved 3-10-2018

United Nations Sustainable Development Goals (2018). https://www.un.org/sustainabledevelopment/health/

United Nations (2015). Universal Declaration of Human Rights http://www.un.org/en/udhrbook/pdf/udhr booklet en web.pdf

UNESCO Report (2014). http://www.ibe.unesco.org/fileadmin/user upload/archive/Countries/WDE/2006/SUBSAHARAN AFRICA/Nigeria/Nigeria.htm

Human Development Report. (2015). Work for Human Development http://hdr.undp.org/sites/default/files/2015 human development report.pdf

United Nations Development Programme (2018). Human Development Index http://hdr.undp.org/en/composite/HDI

Universal Declaration of Human Rights (UDHR)- United Nations (2015) https://www.un.org/en/udhrbook/pdf/udhr booklet en web.pdf

World Health Organization (2015). World Health Statistics 2015 https://www.who.int/gho/publications/world health statistics/2015/en/

Woods, A. (2001). Women and the Struggle for Socialism https://www.marxist.com/marxism-feminism-class-struggle-emancipation-women.htm

Yaya, S., Uthman, A. O., Amouzou, A., Ekholuenetale, M., and Bishwajit, G. (2018) Inequalities in maternal health care utilization in Benin: a population based cross-sectional study, BMC Pregnancy and Childbirth, Volume 18, Issue 194 (May 31, 2018) https://doi.org/10.1186/s12884-018-1846-6

Zureick-Brown, S., Newby, H., Chou, D., Mizoguchi, N., Say, L., Suzuki, E., and Wilmoth, J. (2013). Understanding global trends in maternal mortality. International perspectives on sexual and reproductive health, 39(1), 32-41. 